\title{
Tourism Productivity and Tourism FDI in Croatia
}

\author{
Jože Perić, Ph.D. Full Professor
}

\author{
Maja Nikšıć Radıć, Ph.D. Assistant Professor \\ Faculty of Tourism and Hospitality Management, University of Rijeka \\ Email: jozep@fthm.hr; majanr@fthm.hr
}

\section{Doi:10.5901/mjss.2015.v6n5s2p425}

\section{Abstract}

The purpose of this paper is to examine the effects of foreign direct investment (FDI) in tourism and other relevant control variables on the tourism productivity of Croatia through a model of extended Cobb-Douglas production function. The study included an analysis of quarterly time series data from 2000(1) to 2012(4). Multiple regression analysis showed that a stock of FDI in tourism has a positive significant effect on the tourism productivity. The initial level of productivity and the educational variable also has positive and significant effect on the tourism productivity. Control of Corruption has a negative and significant effect on the productivity of the sector. Rule of Law, an index of capital openness (KAOPEN) and export have a negative, but not significant effect on the tourism productivity. The results of the research indicated that further Croatian tourism development needs FDI. Furthermore, they suggested the importance of improving the institutional environment that has been proven to have a negative impact on the tourism productivity.

Keywords: tourism productivity; FDI; ADF test; stepwise regression.

\section{Introduction}

The Republic of Croatia is highly dependable on tourism. Tourism provides around $15 \%$ of total Croatian GDP and as such plays a major role in the Croatian economy. Consequently, it is necessary to ensure its continued economic development, which includes an upgrade and expansion of the infrastructure on which it is based. One of the ways of further tourism sector development is certainly a more powerful attraction of the FDI.

In the period from 1993 until today, the FDI inflow in Croatia was influenced by various factors. For example, the very beginning of the observed period was marked by the war in the Republic of Croatia, and then by the Kosovo War. By joining the World Trade Organisation in 2000, Croatia started the inclusion in globalization processes. In 2001 Croatia signed of the Stabilization and Association Agreement with the European Union, in 2002 joined the CEFTA and in 2005 opened the negotiations with the European Union. Inclusion in the European integration process resulted in an increase of the FDI inflows. The consequences of the global financial crisis, which affected developed Western countries in 2008, Croatia has felt in 2009, which resulted in a marked decline in overall investment activity in the country. The signing of the accession of negotiations with the European Union in 2011 prompted a modest growth in FDI.

Although the Republic of Croatia, during the period before the appearance of the financial crisis, has attracted a significant level of FDI, there has been no significant impact on employment growth, export growth and acquisition of new technologies. This was due to the domination of the so-called brownfield FDI and too small levels of so-called Greenfield FDI. In the period from 1993 to 2011, most FDI went into financial intermediation (except for ensuring and retirement funds). The hotel and restaurant sector attracted only 2.3\% of total FDI. In the period from 2001 to 2011 21,207.20 million euros of FDI was invested into tourism. These investments were mainly focused on the reconstruction of the existing capacities located in the most attractive locations.

Despite having many studies that explored the effects of FDI in the Croatian economy (Babić, 2001; Lovrinčević, Butorac and Marić, 2004a.; Lovrinčević, Mikulić and Marić, 2004b.; Škudar, 2005; Sisek, 2005; Hunya and Škudar, 2006; Jovančević, 2007; Kersan-Škabić and Zubin, 2009), there are only a few papers related to FDI in Croatian tourism (Bezić, Nikšić Radić and Kandžija, 2010; Perić and Nikšić Radić, 2011; Kunst, 2011). This is one of the main contributions of this research. Given that the effects of investment differ depending on the sector, the authors recognized the need for researching the impact of FDI on the tourism productivity. The stepwise regression will be used to examine the impact of FDI in tourism and relevant control variables on the gross added value in tourism. 
The aim of this study is to provide answers to the subsequent questions:

What is the impact of FDI in tourism on the Croatian tourism productivity?

What is the impact of relevant control variables on the Croatian tourism productivity?

\section{Literature Review}

Even though tourism is a part of the tertiary sector, an area that is related to FDI in tourism is still practically unexplored (Sinclair, 1991; Zhang, 1999; Dwyer, Forsyth and Dwyer, 2010). However, interest in certain field is constantly growing (Dunning, Kundu, 1982; Endo, K. 2006; Sanford \& Dong, 2000; Craigwell \& Moore, 2007).

The initial research on the effects of transnational corporations in tourism is the work of Dunning, J. and Kundu, S. K. from 1982 (Dunning, Kundu, 1982.). The research was conducted on the example of 418 5-star and 4-star hotels worldwide. They came to the conclusion that the effects of foreign-owned hotels vary depending on the type of tourism, the country of origin of transnational corporations, the host country and the advantages and objectives of individual transnational corporations.

In 1999, Zhang, G. completed a comparative analysis of the economic impacts of FDI in tourism of selected countries of the APEC region - Australia as a developed country, China as a developing country and Hong Kong as a newly industrialized country (Zhang, 1999). The results showed that the effects of transnational corporations in tourism on the GDP is more successful if the country is more developed, and if the country is less developed it has a greater effect on the personal income of employees in the tourism industry.

The recent researches regarding the impact of FDI in tourism are based on testing of so-called FDI-led tourism growth hypothesis (Salleh et al., 2011, 251). The test results of FDI-led tourism growth hypothesis are very diverse. Most of them found one-way causal relationship running from FDI to international tourism arrivals (Tang et al, 2007; Bezić et al, 2010; Zhang et al, 2011; Selvanathan et al, 2012). Also, there are evidences of one-way causal link from the number of foreign tourist arrivals to FDI (Kartircioglu, 2011), and evidences of two-way link between the observed variables (Salleh et al, 2011; Samini et al, 2013).

There are also a few specific case studies of the FDI entry into hotel. The results of the studies showed that foreign hotels have a significant development impact on the local economy (UNCTAD, 2007; IFC, 2010; ODI, 2012).

Considering the above, it is obvious that there is an area for further research of the effects of FDI in tourism. The authors intended to contribute to the understanding of the effects of FDI in tourism on the gross value-added of tourism due to the extremely important expectations of the political authorities in connection with the intensification of efforts directed to the FDI attraction into Croatian tourism.

Closely related to the study of the FDI impact on the tourism productivity, it is necessary to emphasize that in 1958 , Hirschman $(1958,109)$ came to the conclusion that not all sectors have the same potential to absorb foreign technology or connectivity with the rest of the economy. The diverse impact of FDI on the productivity of each sector has been proven by numerous recent studies (Alfaro, 2003; Tondl and Fornero, 2010; Cipollina, Giovannetti, Pietovito and Pozzolo, 2012).

\section{Data Set and Methodological Framework}

\subsection{Data}

This research employs quarterly time series data from Q1 2000 to Q4 2012. A small number of observations are a common feature of empirical studies related to the area of South - Eastern Europe.

Analysed time series data were obtained from different sources. The data associated with the independent variable, the gross value added, were obtained from the Central Bureau of Statistics. The tourism productivity is seen through the level of gross value added in the sector. The authors' assumption is that a higher FDI stock in tourism is resulting in a positive effect on the tourism productivity.

The initial conditions in the tourism sector are approximate by the initial value of the gross value added. The importance of the inclusion of initial conditions is emphasized back in 1992 by Levine and Renelt. It is generally expected that a sector that is growing rapidly in the past is less likely to continue rapid growth in the future. In other words, the higher level of initial gross added value has a negative effect on the growth of gross value added, while in poor countries, ceteris paribus, the added value is growing faster than in rich countries.

The main variable of the research, the FDI stock in tourism, is taken from the Croatian National Bank. The variable is deflated by the implicit deflator of gross investment and reduced to the base year 2005. 
Data analysis will be performed by EViews 8.

\subsection{Model Specification}

In remainder of this paper the research of the effects of FDI in the Croatian tourism is conducted. The objective is to evaluate the production performance of FDI in tourism through the following empirical model, or extended Cobb-Douglas production function:

$\log b d v_{-} t_{t}=\alpha_{0}+\beta_{1} \log b d v_{-} t_{t-1}+\beta_{2} \log f d i_{-} t_{t}+\beta_{3} \operatorname{logrlaw}_{t}+\beta_{4} \operatorname{logservex}_{t}+\beta_{5} \log _{\text {locprs }}+\beta_{6} \log _{\text {skill }}+$ $\beta_{7} \mathrm{co}_{t}+\mu_{t}$

where the logarithm of the sector productivity $\left(\log b d V_{t}\right)$ is measured by the gross value-added sectors and explained by its initial level (loginitiallbdvt); intensity of FDI in tourism is measured by FDI stock (logfdit); institutional variable is measured by the Rule of Law (logrlaw); educational variable is measured by the number of highly educated workers in the tourism (logskillint); export variable is measured by tourism revenues as a percentage of total exports of goods and services (logservex), level of corruption is measured by the Control of Corruption (logccprs) and the openness of the country to international financial capital is measured by KAOPEN index (logco). Detailed overview of variables included in the model is presented in table below.

Table 1. Description of variables used in the study

\begin{tabular}{|c|c|c|c|}
\hline & & Abbreviation & Description \\
\hline 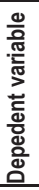 & Gross value added & Logbdv_t & $\begin{array}{l}\text { Definiton: } \\
\text { The logarithm of gross value added (GVA) in the activity I. The variable is deflated (deflator of } \\
\text { GVA 2005) and it comes to the real value of GVA in euros. The variable is seasonally adjusted } \\
\text { (CENSUS X-12) } \\
\text { Source: Central Bureau of Statistics }\end{array}$ \\
\hline \multirow{7}{*}{ 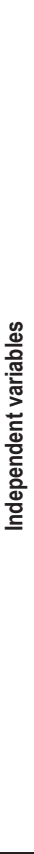 } & Initial gross value added & Loginitiallbdv_t & $\begin{array}{l}\text { Definiton: } \\
\text { The logarithm of gross value added (GVA) in the activity I. The variable is deflated (deflator of } \\
\text { GVA 2005) and it comes to the initial real value of GVA in euros. The variable is seasonally } \\
\text { adjusted (CENSUS X-12) } \\
\text { Source: Central Bureau of Statistics }\end{array}$ \\
\hline & Foreign direct investment & Logfdi_t & $\begin{array}{l}\text { Definiton: } \\
\text { The logarithm of the stock of foreign direct investment (FDI) in the activity I. The variable is } \\
\text { deflated (GFCF-deflator 2005) and it comes to the real value of FDI. } \\
\text { Source: Croatian National Bank }\end{array}$ \\
\hline & Educational variable & Logskillint & $\begin{array}{l}\text { The logarithm of the workers with higher education in the activity I. The variable is seasonally } \\
\text { adjusted (CENSUS X-12). } \\
\text { Source: Authors' calculations according to Central Bureau of Statistics' data }\end{array}$ \\
\hline & Institutional variable & Logrlaw & $\begin{array}{l}\text { The logarithm of the index of law and order which runs from } 0-1 \text {, higher index means lower } \\
\text { political risk. The value of annual data is attributed to the respective quarters. } \\
\text { Source: International Country Risk Guide (ICRG), PRS Group }\end{array}$ \\
\hline & Index of corruption & Logccprs & $\begin{array}{l}\text { The logarithm of the index of corruption which runs from 0-1, higher index means lower political } \\
\text { risk. The value of annual data is attributed to the respective quarters. } \\
\text { Source: International Country Risk Guide (ICRG), PRS Group }\end{array}$ \\
\hline & Export variable & Logservex & $\begin{array}{l}\text { The logarithm of tourism revenue as a percentage of total exports of goods and services. The } \\
\text { variables are deflated (deflator of GVA 2005) and it comes to the real values. The variable is } \\
\text { seasonally adjusted (CENSUS X-12). } \\
\text { Source: Authors' calculations according to Central Bureau of Statistics' and Croatian National } \\
\text { Bank' data }\end{array}$ \\
\hline & Capital Openness & Logco & $\begin{array}{l}\text { Chinn-Ito index (KAOPEN) is an index that measures a country's degree of capital account } \\
\text { openness. KAOPEN encodes tabular overview of limitations of cross-border financial } \\
\text { transactions set out in the IMF's Report on Exchange Arrangements and Exchange Restrictions } \\
\text { (AREAER). The index runs from - } 1.85 \text { to } 2.5 \text {, and a higher value indicates a smaller number of } \\
\text { restrictions on capital account, i.e. a smaller number of national restrictions on capital account. } \\
\text { The value of annual data is attributed to the respective quarters. } \\
\text { Source: http://web.pdx.edu/ ito/Chinn-Ito_website.htm }\end{array}$ \\
\hline
\end{tabular}

Following the model of Hall and Jones who in 1999 concluded that the productivity is linked to the institutional factors, the study introduces institutional variables. Index of law and the control of corruption indicate the quality of the bureaucracy, legislative and the legal framework and the level of corruption. Enhanced institutions, improved bureaucracy and the lower levels of corruption lead to increased productivity of sectors (Tondl and Fornero, 2008). In accordance with existing 
studies, it is expected that the institutional variables are going to have a negative effect in the Croatian example. Institutional variables affect the productivity of the sector (Tondl and Fornero, 2008). These variables are related to the quality of the bureaucracy, legal and legislative system, the level of corruption and the political risk (Meyer and Sinani, 2009). Higher sector productivity is associated with better institutions, better bureaucracy and lower levels of corruption.

So far, a number of studies emphasized the role of the educational variable. Back in 1991, Romer promoted the idea that educated workforce has the potential to generate and implement new technologies and to stimulate growth. In 1998, Borensztein et al., on the example of developing countries, had proved that FDI has a positive effect on the growth rate of the destination country only if the level of human capital is above a certain level. In 2007, Alfaro and Charlton showed that FDI is associated with a higher rate of growth of value added of each sector if the sector has a higher percentage of highly educated workforces. Following the example of Carlin and Mayer (2003), Alfaro and Charlton (2007) and Cipollina, et al. (2011), the share of highly educated employees in this sector is used as a measure of the level of education.

Variable of internationalization, i.e. export variable, is expressed as a share of revenues from tourism in the total exports of goods and services and is included in the model along the lines of Tondo and Forner, 2008. It is believed that the high proportion of export is connected with high productivity. This is due to the fact that exporters have to be more productive in order to compete on the world market, generate more profits with regard to product innovations and enjoy economies of scale arising from the presence on the international market. The above has been established in 1985 by Helpman and Krugman.

The index of financial openness is taken along the lines of Cipollina, et al. (2011) and Reinhardt and Dell'Erba (2013). KAOPEN index attempts to measure the intensity of capital controls because the intensity is correlated with the presence of other restrictions on international transactions (Chinn and Ito, 2006). The index is included in the analysis because the openness of international financial capital is considered synonymous with financial integration with the global economy (European Commission, DG, 2010). There are three main theoretical concepts of benefits arising from the openness of the capital or allowing the free movement of capital (Baele et al., 2004): more chances for sharing and risk diversification, a better allocation of capital within the investment opportunities and the potential for higher growth.

\subsection{Research Methodology}

In order to evaluate the effects of FDI on the tourism productivity, the authors used a stepwise regression analysis.

The existing theory does not provide an answer to the problem of a priori determination of the independent variables that should be included in the empirical model evaluation of the FDI effects on the tourism productivity of the Republic of Croatia (Cf. Akin, 2005). Although there are numerous empirical studies on the relationship between FDI and tourism productivity, research results are very variegated which clearly points to the need to analyse the variables on a specific example, i.e. on a specific country, (in this paper on the tourism sector of the Republic of Croatia) so the results can be more credible. In the multiple regression models, and as a result of the introduction of a large number of variables in the model, there may be many problems. The question arises as whether certain variables should be excluded from the model, that is, which variables should be in the model to meet all the prerequisites of stochasticity under the condition that such a model is well explained, and that the application of such a model can reliably predict the movement of certain phenomena in the future (Jurin, 2007). The stepwise regression was used along the lines of Tondo and Forner (2008) in order to assess the effects of FDI on the tourism sector.

One of the advantages of aforementioned stepwise regression analysis is the simplicity of the procedure of selecting variables and ease of interpretation. It is necessary that the researcher is familiar with the theory to ensure that the relevant variables always remain included in the model (Agung, 2011). It is possible to distinguish between the forward stepwise regression analysis, the backward stepwise regression analysis or a combination thereof. In the forward stepwise regression analysis the variables are excluded one by one and only those that are statistically significant are included in the model. By contrast, backward stepwise regression analysis includes all variables and then those that least contribute to the discriminatory power of the model are excluded.

This study will use a combination of forward and backward stepwise regression analysis. The aim of the authors is to evaluate how each additional control variable affects the effects of FDI, which requires the use of forward method. On the other hand, given the small sample size, it is also necessary to use backward method with high p-value, such as 0.20 or 0.50 (Steyerberg et al., 2000). The advantage of the parallel use of both methods is that the variables can be added or dropped early in the process and the possibility of subsequent changes is simpler (Faraway, 2002). The disadvantage of this approach is that adding or dropping one by one variable may result in the omission of the optimal variable, including the results of the validation of p-value as a consequence of multiple testing (Faraway, 2002). 


\section{Findings and Discussion}

\subsection{Preliminary Testing}

On the very beginning of the study the correlation between the dependent variable of gross value added of tourism and other underlying variables, i.e. the initial level of gross value added, FDI in tourism, exports, educational variables, political stability, control of corruption and KAOPEN-index is examined. The above mentioned are shown in the table below.

Table 2. Pearson's correlation coefficient

\begin{tabular}{|l|c|}
\hline & LOGGVA_T \\
\hline LOGGVA_T & 1.000000 \\
LOGINITIALLBDV_T & 0.989002 \\
LOGFDI_T & 0.813026 \\
LOGCCPRS & -0.553286 \\
LOGCO & 0.762623 \\
LOGRLAW & -0.661342 \\
LOGSERVEX & 0.179547 \\
LOGSKILL & 0.845555 \\
\hline
\end{tabular}

Source: Authors' calculations.

The correlation results indicate that the gross value added of the tourism is positively correlated with the initial level of gross value added, the stock of FDI, export, educational and KAOPEN-index, and negatively correlated with the index of control of corruption and rule of law index.

Extremely strong positive correlation of initial level of gross value added (0.989002) could create a problem of multicollinearity, but despite that, it was necessary to use it in the model due to the aforementioned theoretical assumptions.

The data stationarity can strongly affect the research results and lead to spurious regression and it is necessary to examine it. Stationarity is tested by the ADF test where two hypotheses are being tested:

$\mathrm{H}_{0}: \delta=0$ (the presence of unit root)

$\mathrm{H}_{1}: \delta \neq 0$ (series are stationary).

The acceptance or rejection of the null hypothesis is based on a following decision rule:

- If $\mathrm{t}^{*}$ is $>A D F$ crital value $=>$ the null hypothesis is not rejected (i.e. there is a unit root)

- If $t^{*}$ is $<A D F$ critical value $=>$ the null hypothesis is rejected (i.e. there is no unit root)

The results of the ADF test of the variables are summarized in the table.

Table 3. ADF test results

\begin{tabular}{|c|c|c|c|c|c|c|}
\hline \multirow{2}{*}{ Variable } & \multicolumn{3}{|c|}{ Level } & \multicolumn{3}{|c|}{ First difference } \\
\hline & Constant & Constant + trend & None & Constant & Constant + trend & None \\
\hline LOGBDV_T & $-5.19 * \star \star$ & -1.65 & 4.39 & $-2.89^{\star}$ & $-7.64^{\star \star \star}$ & $-1.73^{*}$ \\
\hline LOGFDI_T & $-2.91^{\star \star}$ & -1.59 & 1.66 & $-6.16^{\star \star \star}$ & $-6.75^{\star \star \star}$ & $-5.94^{\star \star \star}$ \\
\hline LOGCCPRS & -1.23 & -1.98 & 0.67 & $-7.03^{\star \star \star}$ & $-7.05^{\star \star \star}$ & $-7.00^{\star \star \star}$ \\
\hline LOGCO & -1.85 & -1.65 & -0.16 & $-7.07^{\star \star \star}$ & $-7.15^{\star \star \star}$ & $-7.00^{\star \star \star}$ \\
\hline LOGRLAW & -0.642 & -1.970 & 0.841 & $-7.071^{\star \star \star}$ & $-7.061^{\star \star \star}$ & $-7.000^{\star \star \star}$ \\
\hline LOGSERVEX & 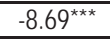 & $-9.08^{\star \star \star}$ & -0.44 & $-9.19 \star \star \star$ & $-9.17^{\star \star \star}$ & $-9.28^{\star \star \star}$ \\
\hline LOGSKILL & -0.140 & $-3.516^{\star \star}$ & 1.956 & $-3.496^{\star \star}$ & -2.623 & $-1.691^{\star \star}$ \\
\hline
\end{tabular}

Note: - P-value significance: ${ }^{* * *} p<0.01,{ }^{* *} p<0.05,{ }^{*} p<0.1 ;$ - Number of lags in the model is determined based on the Schwarz information criteria.

Source: Authors' calculations.

The implementation of the ADF test indicates the fact that, when it comes to data in levels, it is not possible to reject the null hypothesis, i.e. the series are not stationary, and therefore there is the presence of a unit root. The null hypothesis is rejected when the first differentiation of variables is used. Therefore, the observed data series are integrated of the same order, I (1). Considering the fact that the variables are stationary, it is possible that there is a short-term and a long-term 
relationship among the variables. Hence, the next step is to examine the co-integration.

Prior to the implementation of the Johansen test, the optimal number of lag length was examined and serial correlation of the residuals of the VAR models was tested. The results' selection of the optimal number of lag variables indicate the possibility of choosing either 1 or $3 \mathrm{lag}$, but when the serial correlation of residuals are examined, it is clear that it is enough to choose two lags in order to eliminate the correlation (at a significance level of $5 \%$ ). The table below summarizes the Johansen co-integration test results.

Table 4. Johansen co-integration test

\begin{tabular}{|c|c|c|c|}
\hline $\boldsymbol{r}$ & Eigenvalue & Critical value & p value \\
\hline $\mathbf{0}$ & 0.773000 & 159.5297 & 0.0000 \\
\hline $\mathbf{1}$ & 0.632115 & 125.6154 & 0.0000 \\
\hline $\mathbf{2}$ & 0.583968 & 95.75366 & 0.0002 \\
\hline $\mathbf{3}$ & 0.525085 & 69.81889 & 0.0025 \\
\hline $\mathbf{4}$ & 0.390658 & 47.85613 & 0.0281 \\
\hline
\end{tabular}

Source: Authors' calculations.

The results indicate that there are at least 4 co-integration vectors, affirming the $\mathrm{H}_{0}$ at $\mathrm{r} \leq 4$ at a $5 \%$ significance level. Since the variables' co-integration has been proven, it is sufficient to include the logarithmic values of the variables in the regression model.

The preliminary tests showed that the series are integrated of the same order, I (1) and are also co-integrated. In such a case it is possible to estimate the OLS regression model with data used in the level indicating a long-term relationship between the variables.

\subsection{Regression Results}

The research results presented in the table show that the tourism productivity is highly dependent on the initial level of productivity. In other words, one lag length is need to stimulate sector productivity, i.e. the level of productivity in the previous period encourages further sector productivity growth.

Table 5. Empirical evidence

\begin{tabular}{|c|c|c|c|c|c|c|}
\hline \multicolumn{7}{|c|}{ Dependent variable: LOGGVA_T } \\
\hline Variable & (1) & (2) & (3) & (4) & (5) & (6) \\
\hline LOGINITIALLGVA_T & $\begin{array}{l}0.775^{\star * *} \\
{[0.0000]}\end{array}$ & 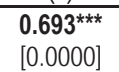 & 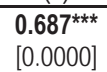 & $\begin{array}{l}0.713^{\star \star *} \\
{[0.0000]}\end{array}$ & 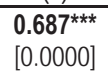 & $\begin{array}{l}0.702^{* * *} \\
{[0.0000]}\end{array}$ \\
\hline LOGFDI_T & $\begin{array}{l}0.075^{\star \star \star} \\
{[0.0010]}\end{array}$ & $\begin{array}{l}0.087^{* * *} \\
{[0.0001]}\end{array}$ & $\begin{array}{l}0.082^{* * *} \\
{[0.0001]}\end{array}$ & $\begin{array}{l}0.106^{\star * *} \\
{[0.0012]}\end{array}$ & $\begin{array}{l}0.082^{\star * *} \\
{[0.0002]}\end{array}$ & $\begin{array}{l}0.088^{* * *} \\
{[0.0002]}\end{array}$ \\
\hline LOGSKILL & & $\begin{array}{l}\mathbf{0 . 0 8 9} \mathbf{9}^{\star \star \star} \\
{[0.0053]}\end{array}$ & $\begin{array}{l}0.081^{* * *} \\
{[0.0097]}\end{array}$ & & $\begin{array}{c}0.081^{* \star} \\
{[0.0107]}\end{array}$ & $\begin{array}{c}0.075^{\star *} \\
{[0.0202]}\end{array}$ \\
\hline LOGCCPRS & & & $\begin{array}{c}-0.079^{*} \\
{[0.0633]}\end{array}$ & & $\begin{array}{c}-0.079^{*} \\
{[0.0688]}\end{array}$ & $\begin{array}{c}-0.077^{*} \\
{[0.0740]}\end{array}$ \\
\hline LOGRLAW & & & & $\begin{array}{c}-0.280 \\
{[0.1699]}\end{array}$ & & \\
\hline LOGCO & & & & & & $\begin{array}{c}-0.019 \\
{[0.4429]}\end{array}$ \\
\hline LOGSERVEX & & & & & $\begin{array}{c}-0.002 \\
{[0.9627]}\end{array}$ & $\begin{array}{c}-0.008 \\
{[0.8179]}\end{array}$ \\
\hline R-squared & 0.983 & 0.986 & 0.987 & 0.984 & 0.987 & 0.987 \\
\hline Adj. R-squared & 0.982 & 0.985 & 0.986 & 0.982 & 0.985 & 0.985 \\
\hline F-statistic & $1291.24^{\star \star \star}$ & $1009.50^{\star \star \star}$ & $803.39^{\star \star \star}$ & $879.60^{\star \star \star}$ & $627.80^{\star \star \star \star}$ & $518.29^{\star \star \star \star}$ \\
\hline Observation & 48 & 48 & 48 & 48 & 48 & 48 \\
\hline $\mathrm{VIF}^{1}$ & $<2.54$ & $<5.78$ & $<5.82$ & $<9.82$ & $<5.83$ & $<7.50$ \\
\hline
\end{tabular}

Note: $p$-values in parentheses ${ }^{* \star *} p<0.01,{ }^{* *} p<0.05,{ }^{*} p<0.1$

1 refers to the highest VIF value of the variable in the model.

Source: Authors' calculations. 
FDI also has a positive significant effect on the tourism productivity. This means that the stock of FDI in the tourism affected the tourism productivity growth in the observed period. The result above is in line with the previous research of Tondo and Forner (2008).

The inclusion of educational variable in column (2) also indicates a positive significant effect on the tourism productivity. Positivity and significance of the coefficient is proof that technical services such as tourism services, which involve a skilled workforce to increase productivity, are present in the Croatian tourism. Considering the above, the result supports the opinion that higher level of education and higher quality workforce also means higher productivity.

Index of corruption control is included in the column (3) and points to the negative and significant effect on the tourism productivity. Such a result is expected. Corruption itself is a threat to the FDI.

The inclusion of institutional variable, rule of law, in column (4), and dropping of educational variable and control of corruption index (due to the high multicollinearity) indicates a negative, but not significant effect. This result is in line with the research results of Tondl and Forner (2008), but with the opposite sign. The weakness of institutions, excessive bureaucracy and inefficient government are usually the obstacles to FDI and sectors productivity. Political risk certainly affects tourism activities.

When the model includes export of sector (column 5), educational variable and control of corruption index, and due to the high multicollinearity omits institutional variable, the results remain unchanged. Export variable has a negative, but not significant effect on the productivity of the sector.

Inclusion of all the variables in the model, with exception of institutional variable (column 6), the importance of FDI for the tourism productivity does not change. All the control variables, excluding educational variable, have a negative effect on the tourism productivity. The last included variable, KAOPEN, has a negative, but not significant effect on the tourism productivity. This is consistent with the research of the European Commission for Internal Market \& Services (EC DG, 2010). Croatia, as well as most of EU countries, did not react by restricting the capital openness in times of financial crisis.

\section{Concluding Remarks}

The study examined the effects of FDI stock in tourism and other relevant control variables on the tourism sector productivity through a model of extended Cobb-Douglas production function. The study included an analysis of secondary quarterly data for the period from 2000(1) to 2012(4).

The economic impacts of FDI in tourism have been confirmed by multiple regression analysis of appointed econometric model which revealed that the FDI stock in tourism has a positive significant effect on the tourism productivity. In other words, the FDI stock in the tourism sector affected the tourism sector productivity growth in the observed period. Tourism productivity is also highly dependent on the initial level of productivity. Educational variable also has positive and significant effect on tourism productivity. Control of Corruption has a negative and significant effect on the productivity of the sector. Rule of Law, an index of capital openness (KAOPEN) and export have a negative, but not significant effect on the tourism productivity.

The results of the research indicated that further Croatian tourism development needs FDI. Furthermore, they suggested the importance of improving the institutional environment that has been proven to have a negative impact on the tourism productivity.

\section{References}

Agung, I. G. N., (2011), Cross Section and Experimental Dana Analysis Using EViews, John Wiley\&Sons.

Akinlo, A. E., (2005), Impact of Macroeconomic Factors on Total Factor Productivity in Sub-Saharan African Countries, World Institute for Development Economics Research, Research paper No. 2005/39.

Alfaro, L., Charlton, A., (2007), Growth and the Quality of Foreign Direct Investment: Is All FDI Equal?, Harvard Business School Working Paper 07-072.

Babić, A., A. Pufnik, AND T. Stučka, (2001), The theory and reality of foreign direct investment in the world and in transition countries with special reference to Croatia, www.hnb.hr.

Baele ET AL., (2004), Measuring financial integration in the euro area, European Central Bank. Available at: http://ideas.repec.org/ p/ecb/ecbops/20040014.html [Accessed July 14, 2010].

Bezić, H., M. Nikšić Radić, AND T. Kandžija, (2010), Foreign Direct Investments in the Tourism Sector of the Republic of Croatia, Valahian Journal of Economic Studies - an international review of theories and applied studies in performance management, 1(15):21-28.

Borensztein, E., DE Gregorio, J., LEE, J. W., (1998), How does Foreign Direct Investment Affect economic growth? Journal of 
International Economics 45, p. 115-135.

Carlin, W., MAYER, C., (2003), Finance, Investment and Growth, Journal of Financial Economics 69, p. 191-226.

Cipollina ET AL: FDI and Growth, (2011), What cross-country industry data say, Ministry of Economy and Finance, Department of the Treasury, Working Papers, No 10.

Chinn, M. D., ITO, H., (2006), What matters for financial development? Capital controls, institutions, and interactions, Journal of Development Economics 8, $163-192$.

Craigwell, R., \& Moore, W. (2007). Foreign direct investment and tourism in SIDS: Evidence from panel causality tests. Tourism Analysis, 13(4), p. 427-432.

Dunning, J., Kundu, S. K., (1982) Impact of Transnational Hotel Chains and Management Companies Operating in Developing Countries u Transnational Corporations in International Tourism, United Nations, http://unctc.unctad.org/data/e82iia9b.pdf (20.04.2013.).

Dwyer, L., P. Forsyth, AND W. Dwyer, (2010), Tourism Economics and Policy, (Cheltenham: Channel View Publications).

EC DG Internal Market \& Services, (2010), Analysis of Developments in the Fields of Direct Investment and M\&A - 2010 Report, Part II: The Role of the Free Movement of Capital in a Period of Crisis and Recovery, London Economics.

Endo, K. (2006). Foreign direct investment in tourism - flows and volumes. Tourism Management.

Faraway, J. J., (2002), Practical Regression and Anova using R.

Hall, R. E., Jones, C. I., (1999) Why do some countries produce so much more output per worker than others?, Quarterly Journal of Economics, 114(1), p. 83-116.

Helpman, E., Krugman, P., (1985), Market Structure and Foreign Trade, Cambridge, MIT Press.

Hunya, G. and A. Škudar, (2006.), The Role of Foreign Direct Investments in the Croatian Economy", The Vienna Institute for International Economic Studies, http://www.wiiw.ac.at.

Jovančević, R. (2007.), The Impact of Foreign Investments Flows on Croatian Economy- A Comparative Analysis», Ekonomski pregled, 58(12):826-850.

Jurin, E., (2007), Quantitative methods in economics, Faculty of Economics, University of Split, Split.

Katircioglu, S. T. (2009). Revisiting the tourism-led-growth hypothesis for Turkey using the bounds test and Johansen approach for cointegration. Tourism Management, 30(1), 17-20.

Kersan-Škabić, I. and C. Zubin, (2009), The impact of foreign direct investment to GDP growth, on employment and on the export to Croatia. Economic Review, 60 (3/4):119-151.

Kunst, I., (2011), Foreign direct investment in Croatian tourism: the condition and limits, Tourism, 59(2):225-241.

Lovrinčević, Ž., G. Buturac, and Marić, Z., (2004), The inflow of foreign capital - the effect on domestic investment and the structure of trade, Economic Review, 55(11-12):894-934.

Lovrinčević, Ž., D. Mikulić and Z. Marić, (2004), Investment efficiency and FDI - an old story, new circumstances, Economic Review, 55(1-2):3-43

Meyer, K. A, Sinani, E., (2009), When and where does foreign direct investment generate positive spillovers? A meta-analysis, Journal of International Business Studies, Vol. 40, No. 7, pp. 1075-1094.

Odi (2012), Investing in hotels and demonstrating development impact: Case study of IFC's investment in the Serena Kigali Hotel, Rwanda http://www.ifc.org/wps/wcm/connect/2e8ac3004b885faebb8ffbbbd578891b/Serena+Kigali+CS.pdf?MOD=AJPERES.

Perić, J., and M. Nikšić Radić, (2011), Sustainable Foreign Direct Investment in Tourism Sector of Developing Countries, 1st International Scientific Conference, Tourism in South East Europe 2011, (Opatija: Fakultet za menadžment u turizmu i ugostiteljstvu).

Romer, D., (1989), Endogenous Technological Change, Working Paper No. 3210, National Bureau of Economic Research, http://recce. org/AE/romer1990.pdf.

Reinhardt, D., Dell'erba, S., (2013), Not all capital waves are alike: a sector-level examination of surges in FDI inflows, Working paper No. 474, Bank of England.

Salleh, N. H. M., R. Othman, \& Sarmidi, T, (2011), An Analysis of the Relationships between Tourism Development and Foreign Direct Investment: An Empirical Study in Selected Major Asian Countries. International Journal of Business Social Science, 3 (2), p. 250-257.

Samimi, A. J., S. Sadeghi, \& Sadeghi, S, (2013), The Relationship between Foreign Direct Investment and Tourism Development: Evidence from Developing Countries. International Journal of Institutions and Economies, 5(2), 59-68.

Sanford, D.M., \& Dong, H., (2000), Investment in familiar territory: tourism and new foreign direct investment. Tourism Economics, 6(3), 205-219.

Selvanathan, S., E. A. Selvanathan, \& Viswanathan, B. (2012). Foreign Direct Investment and Tourism: Empirical Evidence from India, Tourism Analysis, 17(1), 91-98.

Steyerberg EW, Eijkemans MJ, Harrell FE, JR., Habbema JD., (2000), Prognostic modelling with logistic regression analysis: a comparison of selection and estimation methods in small data sets. Stat Med, 19(10=, 59-1079.

Tang, S., E.A. Selvanathan, \& Selvanathan, S., (2007), The relationship between foreign direct investment and tourism: empirical evidence from China, Tourism Economics, 13(1), 25-39.

Sinclair, M. T., and M. J. Stabler, (1991), The Tourism Industry: An International Analysis, (UK: C.A.B. International).

Sisek, B. (2005), Foreign direct investments in Croatia - causes of failure, Proceedings of the Faculty of Economics in Zagreb, 3, 89 108.

Škudar, A., (2005), The effects of direct investment in Croatia, Customs News. 5, 48-58 
Tondl, G. I Fornero, J. A., (2008), Sectoral Productivity and spillover effects of FDI in Latin America, Europainstitut, Wirtschaftsuniversitat Wien.

Zhang, G., (1999), A Comparative Study of the Economic Impact of Tourism Investment on Selected Economies of Apec Region, (Hong Kong: The Hong Kong Polytechnic University).

Zhang, J., Ebbers, H., ZHOU, C., (2011), Flows of Tourists, Commodities and Investment: The Case of China, Tourism Economics. 